\title{
New records of Vieira flinti Sosa \& Tauber, 2017 (Neuroptera, Chrysopidae) from Brazil
}

\author{
Marcoandre Savaris ${ }^{1}$, Hugo Leoncini Rainho ${ }^{1}$, Rafaela Cristina dos Santos ${ }^{1}$, \\ Caleb Califre Martins ${ }^{2}$
}

1 Universidade de São Paulo, Escola Superior de Agricultura "Luiz de Queiroz" (USP-ESALQ), Departamento de Entomologia e Acarologia, Avenida Pádua Dias, 11, CEP 13418-900, Piracicaba, SP, Brazil. 2 Universidade de São Paulo, Faculdade de Filosofia, Ciências e Letras de Ribeirão Preto (USP-FFCLRP), Departamento de Biologia, Avenida dos Bandeirantes, 3900, CEP 14040-901, Ribeirão Preto, SP, Brazil.

Corresponding author: Marcoandre Savaris, savaris@usp.br

\begin{abstract}
Vieira Navás, 1913 is a small genus of green lacewings of the Neotropical region with 5 recognized species. One species, Vieira flinti Sosa \& Tauber, 2017, was recently described from Venezuela and northeastern Brazil. In this study, we record V.flinti for the first time in the states of São Paulo (at Piracicaba) and Mato Grosso do Sul (at Campo Grande) in the Southeast and Midwest regions of Brazil, respectively. Photographs and a distribution map are provided.
\end{abstract}

\section{Key words}

Chrysopinae; Belonopterygini; green lacewings; geographic distribution; Neotropical region.

Academic editor: Tiago K. Krolow | Received 30 May 2018 | Accepted 25 June 2018 | Published 20 July 2018

Citation: Savaris M, Rainho HL, Santos RC, Martins CC (2018) New records of Vieira flinti Sosa \& Tauber, 2017 (Neuroptera, Chrysopidae) from Brazil. Check List 14 (4): 591-594. https://doi.org/10.15560/14.4.591

\section{Introduction}

Vieira Navás, 1913 (Neuroptera, Chrysopidae) is a small and Neotropical genus of lacewings (Sosa and Tauber 2017). This genus was originally included in the tribe Leucochrysini, but Tauber (2007) transferred it to the Belonopterygini based on morphological features of larvae and adults. Five species are recognized in the genus: Vieira iridea (Olivier, 1793) from Suriname, which was considered nomen dubium by Sosa and Tauber (2017); Vieira brooksi (Tauber, 2006) from Bolivia, Brazil, Panama, Venezuela, and possibly Costa Rica; Vieira elegans (Guérin Méneville, 1844) from Bolivia, Brazil, Guyana, Peru, Trinidad, and Venezuela; and Vieira leschenaulti (Navás, 1913) from Bolivia, Brazil, Colombia, Costa Rica, French Guiana, Peru, and Suriname (Brooks and Barnard 1990, Penny 2002, Tauber 2006, Tauber et al. 2006, Tauber 2007, Sosa and Tauber 2017).
The most recently described species is Vieira flinti Sosa \& Tauber, 2017, originally recorded for Venezuela (Aragua and Yaracuy) and northeastern Brazil (Bahia) (Sosa and Tauber 2017). Here, we document new records of $V$. flinti from the states of São Paulo and Mato Grosso do Sul.

\section{Methods}

Two of our studied specimens were collected in Piracicaba, state of São Paulo, near of the Laboratório de Ecologia Química e Comportamento de Insetos-INCT, of Universidade de São Paulo (USP-ESALQ); a third specimen (previously collected in the state Mato Grosso do Sul) was found deposited in the entomological collection of Museu de Entomologia da ESALQ.

The Vieira flinti specimens were identified according Sosa and Tauber (2017), taxonomical key and the wing 


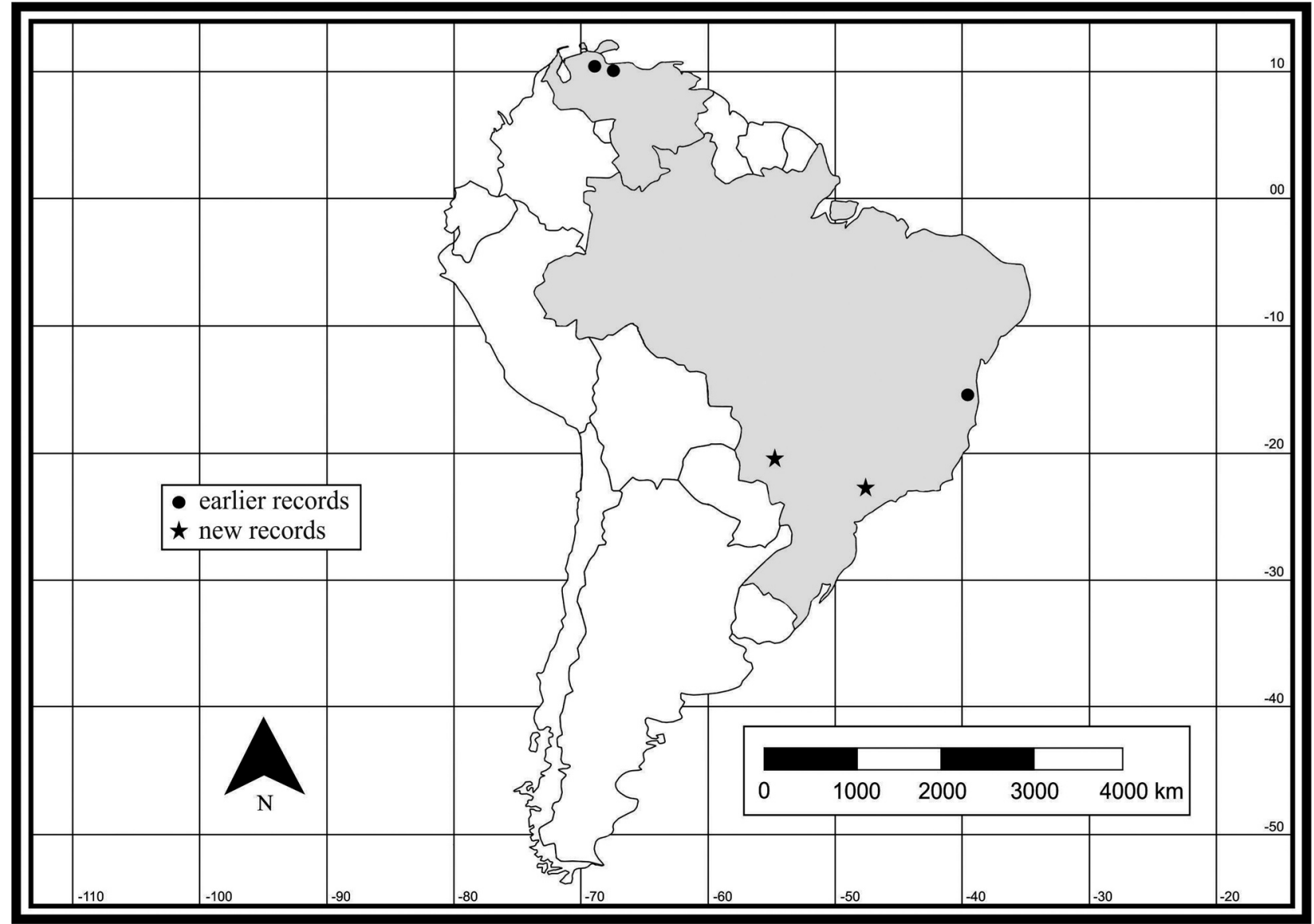

Figure 1. Distribution map of Vieira flinti Sosa \& Tauber, 2017

$=$ previous records, $\star=$ new records.

terminology following Breitkreuz et al. (2017). The specimens were collected under the SISBIO permit \#29705 and deposited in the Museu de Entomologia da ESALQ.

High-resolution photographs were taken in a stereomicroscope (Leica M205C) equipped with a Leica DFC 450 camera. Digital photographs were enhanced using Photoshop CS6.

Distribution maps were made using Quantum GIS 2.8. Longitude and latitude were obtained from specimen labels or estimated using gazetteers and maps. Localities of specimens were plotted on a world land projection using ESRI ArcView.

\section{Results}

New records. Brazil: São Paulo: Piracicaba, Escola Superior de Agricultura "Luiz de Queiroz", Universidade de São Paulo (ESALQ-LEA) (2242'43.93" S, 47³7'42.61" W, 550 m elev.), 6 April 2018, R.C. Santos, 1 male (ESALQ6924-1). Brazil: São Paulo: Piracicaba, ESALQLEA (22 42'42.37" S, 047³7'41.67" W, 548 m elev.), 11 April 2018, H.L. Rainho, 1 female (ESALQ6924-2). Brazil: Mato Grosso do Sul: Campo Grande (20²5'40.40" S, 05443'15.64" W), 22 April 2016, E.C. Lira, 1 female (ESALQ6924-3) (Fig. 1).

Vieira flinti was recorded from São Paulo and Mato Grosso do Sul for the first time, Southeast and Midwest regions of Brazil. The distances between the previous locality, where the paratypes of $V$. flinti were collected in Brazil (Bahia) and the new records of our study are almost 1,700 km to Campo Grande and 1,175 km to Piracicaba. The distance of collection points between Campo Grande and Piracicaba is $776 \mathrm{~km}$. In our opinion, this range of distribution is quite significant.

Of the 2 Piracicaba specimens of $V$. flinti, 1 specimen (ESALQ6924-1) was hand-collected on the lower surface of cabbage leaves, Brassica oleracea L. These same plants also contained the whitefly, Bemisia tabaci (Gennadius, 1889) (Hemiptera, Aleyrodidae). The other specimen of $V$. flinti was collected in a sentinel flight interception trap baited with sulcatol $[(+)$ 6-methyl5-hepten-2-ol] and sulcatone (6-methyl-5-hepten-2-one), attractant pheromones of ambrosia beetles (Coleoptera, Curculionidae, Scolytinae and Platypodinae). The capture of $V$. flinti by trap baited with these wood-boring beetles specific attractants was unexpected. To our knowledge, these pheromones have never been reported as attractants of lacewings. These pheromones probably do not have a biological role in the attraction of $V$. flinti, and in almost 1 year of monitoring at this Atlantic Rainforest remnant by sentinel traps, only 1 specimen of $V$. flinti was collected. The third record, from Mato Grosso do Sul, was from an earlier collection (not ours).

Identification. The genus Vieira is characterized by bodies with dark-brown or blackish marks, by forewings with large brown spots or streaks, and by having a series 


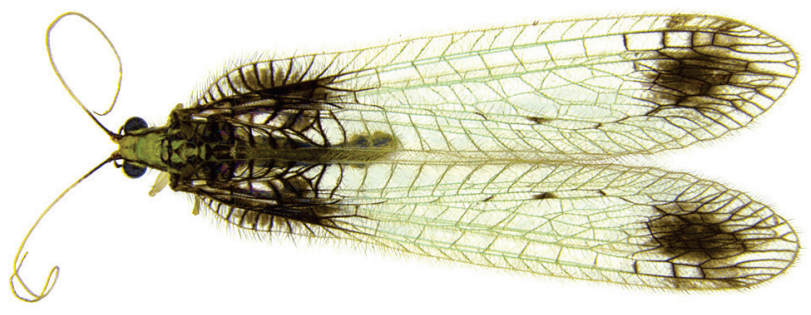

2

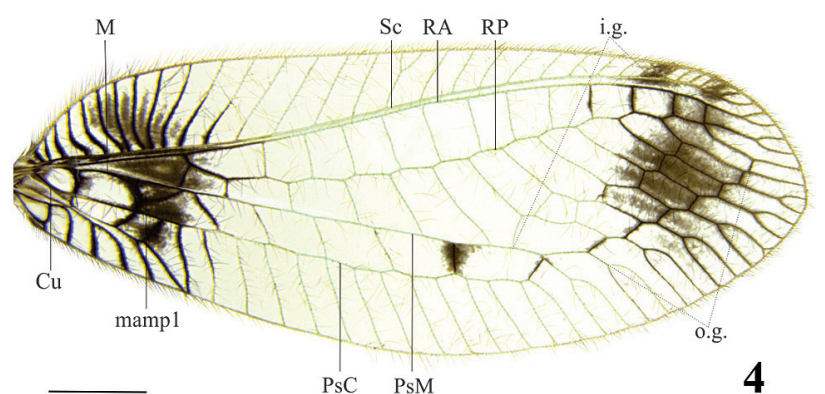

4
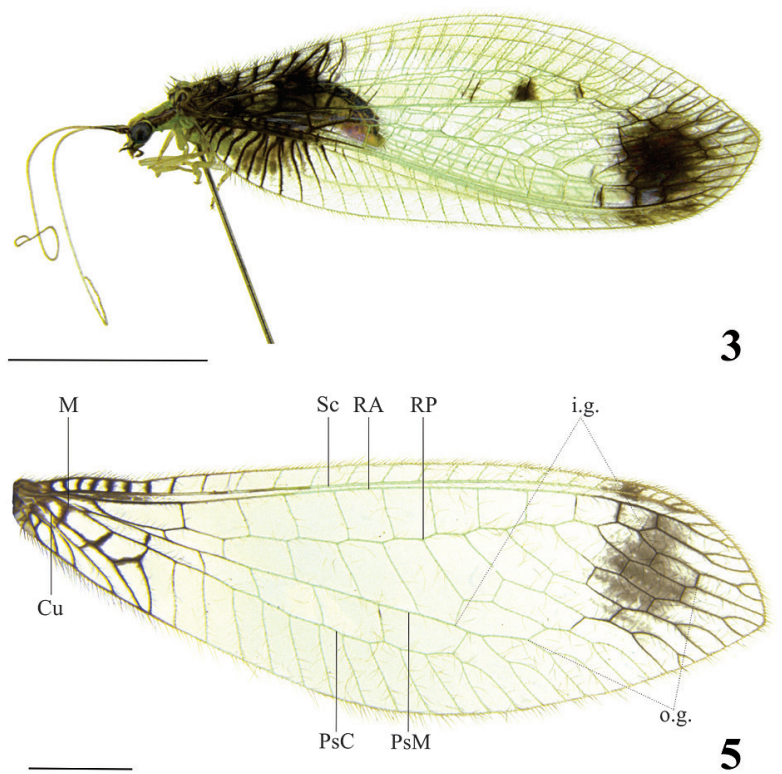

5

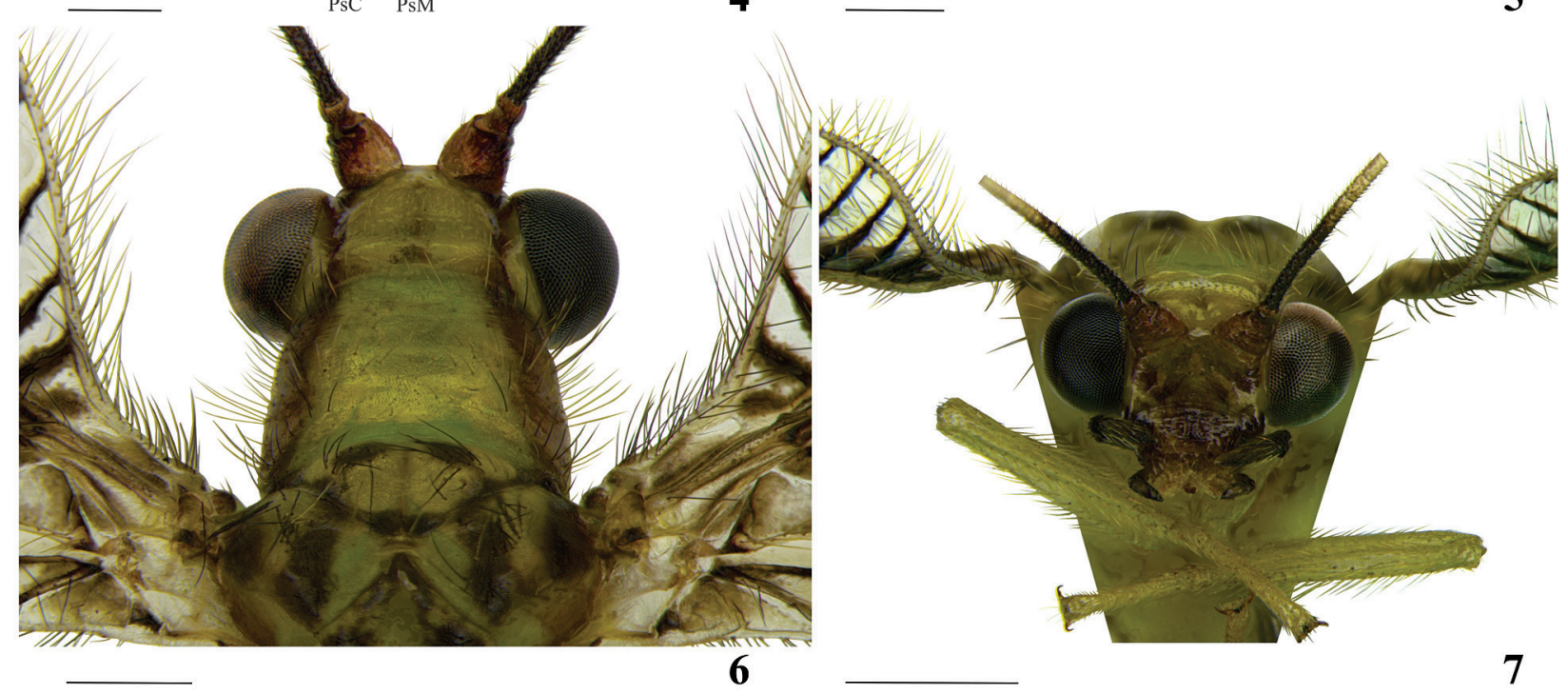

Figures 2-7. Adult of Vieira flinti Sosa \& Tauber, 2017. 2. Habitus, dorsal. 3. Habitus, lateral. 4. Forewing. 5. Hindwing. 6. Prothorax, dorsal. 7. Head, frontal. Abbreviations: $\mathrm{Cu}=$ cubitus, i.g. $=$ intern gradates, $\mathrm{M}=$ medial, mamp1 $=$ first intramedian cell, $\mathrm{PsC}=$ pseudocubital, $\mathrm{Ps} M=$ pseudomedial, $\mathrm{RA}=$ radius anterior, $\mathrm{RP}=$ radius posterior, $\mathrm{Sc}=$ subcosta. Scale bars: Figs $2,3=5 \mathrm{~mm}$; Figs $4,5=2 \mathrm{~mm}$; Figs $6=0.5 \mathrm{~mm}$; Fig. $7=1 \mathrm{~mm}$.

of cross-veins forming a fan surrounded by dark-brown mark on the costal area of the wings (Sosa and Tauber 2017) (Figs 2, 3). According to Tauber et al. (2006), this pattern of dark brown on the body and wings make adults inconspicuous when they are resting on the undersides of mottled foliage in the forest. Vieira flinti is differentiated from other species of the genus by its large size, wings with white veins and diffuse patches of light-brown and brown venation, diffuse marks at the tips of the fore and hindwings that do not reach the wing margin, and the large mark on the forewing base that surrounds approximately 10 costal cross-veins and some medial and cubital cells (Sosa and Tauber 2017) (Figs 4, 5).

Specimens of $V$. flinti in this study are very similar to the original description of the species by Sosa and Tauber (2017) (Figs 2-7). However, the marks on the basal portion of scape and on the frons are almost fused in our specimens (Fig. 7), while in the original description, they are separated. The wings do not show important variation in their membranes and dark-brown marks. The forewings (Fig. 4) have 3 prominent marks: 1 at the basal region of the wing, another connecting the distal part of inner and outer gradates and a third surrounding the penultimate cross-vein between the pseudoveins PsM (pseudomedial) and $\mathrm{PsC}$ (pseudocubital). The pterostima has 2 well-defined dark-brown marks. The first intramedian cell (mampl) is eutriangular and ovate. The hindwing (Fig. 5) has 2 dark-brown marks: the first at basal region of the wing and the second surrounding the distal part of inner and outer gradates. The pterostigma has only 1 dark-brown mark.

\section{Discussion}

The genus Vieira, 1913 has great importance for the understanding of phylogenetic relationships between the genera and tribes of the Chrysopidae, because it 
was originally described as belonging to the tribe Leucochrysini, probably because of the black marks on the wings (characteristic commonly found in the genera of this tribe), and then transferred to Belonopterygini tribe mainly due to the characteristics of its larvae, wings and male genitalia (Tauber 2006, Tauber et al. 2006, Tauber 2007, Sosa and Tauber 2017). All 5 species belonging to Vieira are found only in the tropical region, mainly in the North region of South America and all them except $V$. iridea occur in Brazil mainly in the north and southeast regions (Martins and Machado 2008).

The species most recently described Vieira is $V$. flinti, which was described based on the holotype (from Venezuela) and 3 paratypes ( 2 from Venezuela and 1 from Brazil). Recently, 3 specimens: 1 male and 1 female: from the city of Piracicaba (state of São Paulo) and 1 female from the city of Campo Grande (state of Mato Grosso do Sul) were found. These occurrences increase the number of Brazilian specimens of $V$. flinti from 1 to 4 , as well as its distribution in 2 other Brazilian states (São Paulo and Mato Grosso do Sul) and 2 Brazilian regions (Southeast and Midwest). Our study, which provides the only male specimen reported from Brazil so far, demonstrates that the genus Vieira is more diverse and has a greater distribution than originally believed; this agrees with the observations of Sosa and Tauber (2017). Therefore, we recommend that more fieldwork be carried out in other states of the Brazilian Midwest, Northeast and Southeast regions, with the aim of finding other species of Vieira and possibly expanding the information for those already reported.

\section{Acknowledgements}

This study was supported by the Programa de Pós-Graduação em Entomologia USP/ESALQ, INCT, Instituto Nacional de Ciência e Tecnologia, CAPES, Coordenação de Aperfeiçoamento de Pessoal de Nível Superior (grant \#1754572), CNPq, Conselho Nacional de Desenvolvimento Científico e Tecnológico (grant \#465511/2014-7) and FAPESP, Fundação de Amparo à Pesquisa do Estado de São Paulo (grants \#2014/50871-0 and \#2016/17952-2).
We thank Dr Paul Whitaker Pare (Texas Tech University) for the review of the English and style. We also thank the anonymous reviewers and the subject editor for their help to improve the manuscript.

\section{Author's Contributions}

MS and CCM identified and prepared the specimens; HLR and RCS collected the Piracicaba specimens and took the high-resolution photographs; MS made the distribution map; MS, CCM, HLR, and RCS wrote the text.

\section{References}

Breitkreuz LCV, Winterton SL, Engel MS (2017) Wing tracheation in Chrysopidae and other Neuropterida (Insecta): a resolution of the confusion about vein fusion. American Museum Novitates 3890: 1-44. https://doi.org/10.1206/3890.1

Brooks SJ, Barnard PC (1990) The green lacewings of the world: a generic review (Neuroptera: Chrysopidae). Bulletin of the British Museum Natural History (Entomology) 59: 117-286.

Navás L (1913) Crisópidos sudamericanos. Brotéria (Zoológica) 11: 73-104.

Martins CC, Machado RJP (2018) Chrysopidae in Catálogo Taxonômico da Fauna do Brasil. PNUD. http://fauna.jbrj.gov.br/fauna/ faunadobrasil/644. Accessed on: 2018-06-27.

Penny ND (2002) Family Chrysopidae. In: Penny ND (Ed.) A guide to the lacewings (Neuroptera) of Costa Rica. Proceedings of the California Academy of Sciences 53 (4): 161-457.

Sosa F, Tauber CA (2017) The genus Vieira Navás (Neuroptera: Chrysopidae): a new species, a key to the species, and new geographic records. Zootaxa 4258 (1): 43-59. https://doi.org/10.11646/ zootaxa.4258.1.3

Tauber CA (2006) A new species of Berchmansus (Neuroptera: Chrysopidae) and nomenclatural notes on B. elegans (Guérin Méneville). Proceedings of the Entomological Society of Washington 108 (4): 830-841.

Tauber CA (2007) A review of Berchmansus and Vieira and description of two new species of Leucochrysa (Neuroptera: Chrysopidae). Annals of the Entomological Society of America 100 (2): 110-138. https://doi.org/10.1603/0013-8746(2007)100[110:ROBAVA]2.0 $\mathrm{CO} ; 2$

Tauber CA, Tauber MJ, Albuquerque GS (2006) Berchmansus elegans (Neuroptera: Chrysopidae): Larval and adult characteristics and new tribal affiliation. European Journal of Entomology 103: 21-31. https://doi.org/10.14411/eje.2006.024 